\title{
Architectural differentiation reflects bacterial community structure in stream biofilms
}

\author{
Katharina Besemer ${ }^{1}$, Iris Hödl ${ }^{1}$, Gabriel Singer ${ }^{1}$ and Tom J Battin ${ }^{1,2}$ \\ ${ }^{1}$ Department of Freshwater Ecology, University of Vienna, Vienna, Austria and ${ }^{2}$ WasserCluster Lunz, Dr Carl \\ Kupelwieser Promenade 5, Lunz am See, Austria
}

\begin{abstract}
Laboratory studies have documented the extensive architectural differentiation of biofilms into complex structures, including filamentous streamers generated by turbulent flow. Still, it remains elusive whether this spatial organization of natural biofilms is reflected in the community structure. We analyzed bacterial community differentiation between the base and streamers (filamentous structures floating in the water) of stream biofilms under various flow conditions using denaturing gradient gel electrophoresis (DGGE) and sequencing. Fourth-corner analysis showed pronounced deviation from random community structure suggesting that streamers constitute a more competitive zone within the biofilm than its base. The same analysis also showed members of the $\alpha$-Proteobacteria and Gemmatimonadetes to preferentially colonize the biofilm base, whereas $\beta$-Proteobacteria and Bacteroidetes were comparatively strong competitors in the streamers. We suggest this micro-scale differentiation as a response to the environmental dynamics in natural ecosystems.
\end{abstract}

The ISME Journal (2009) 3, 1318-1324; doi:10.1038/ismej.2009.73; published online 2 July 2009

Subject Category: microbial ecology and functional diversity of natural habitats

Keywords: stream biofilms; differentiation; biodiversity; community structure; architecture; fourthcorner analysis

An important part of prokaryotic biodiversity and biomass is contained in sedimentary and interfacial environments (Whitman et al., 1998). Here microbes form attached and matrix-enclosed biofilms with extensive architectures, including mushroom-like structures, ripples and streamers (Costerton et al., 1995; Hall-Stoodley et al., 2004). Fossil evidence shows that architectural differentiation is an ancient and integral characteristic of biofilms (Hall-Stoodley et al., 2004). However, it remains elusive whether this spatial organization is reflected in the community structure. Illuminating this link is essential to better understand biofilm architectural differentiation as a possible adaptation to the environment.

Laboratory-based studies have extensively documented the differentiation of biofilms into complex structures and morphologies (Costerton et al., 1995; Stoodley et al., 1999; Hall-Stoodley et al., 2004). A remarkable degree of phenotypic diversity can underlie the development of such structures now increasingly considered as a response to stress and

Correspondence: TJ Battin, Department of Freshwater Ecology, University of Vienna, Althanstrasse 14, Vienna, A-1090, Austria. E-mail: tom.battin@univie.ac.at

Received 9 March 2009; revised 27 May 2009; accepted 2 June 2009; published online 2 July 2009 as a dispersal strategy (for example, Koh et al., 2007). Filamentous streamers were repeatedly reported from monospecies or mixed bacterial biofilms and seem largely generated by turbulenceinduced shear (Stoodley et al., 1999). They can form biofilms themselves, develop either directly from the biofilm base or from its canopy, and float in the bulk liquid. Such streamers also form frequently in benthic stream biofilms (Figures 1a and b). They can associate with diatoms (Figure 1c) and other algae to develop extraordinarily long filaments in circumneutral streams (Besemer et al., 2007) and contribute most biomass to acidophilic species-poor biofilms (Hallberg et al., 2006).

In this study, we analyzed bacterial community differentiation between the base (attached to the substratum) and streamers (floating in the water) of biofilms. To capture a large variation of biofilms, we sampled them from various hydrodynamic environments and growth stages. In fact, headwater streams, where biofilms dominate microbial life, are characterized by varying streambed geomorphologies and associated flow conditions. Therefore, we studied biofilm differentiation under controlled laminar, transitional and turbulent flow in laboratory flumes (Singer et al., 2006; Besemer et al., 2007) and in large-scale streamside flumes along triangular 

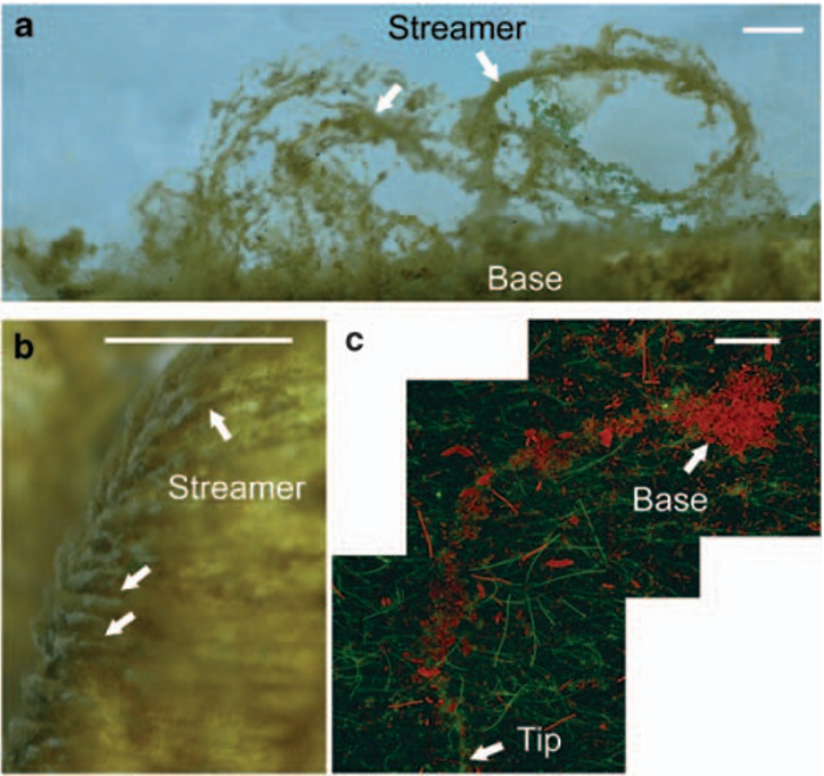

Figure 1 (a) Representative stream biofilm (day 61) from the streamside flumes showing differentiation into the base and streamers; lateral view. The scale bar refers to $5 \mathrm{~mm}$. (b) Macroscopic streamers (day 17) at the crest of a stone on the streambed. Scale bar refers to $5 \mathrm{~mm}$. (c) Streamer (day 8) as seen by epifluorescence microscopy. Bacteria appear green (stained with SYTO 13, Invitrogen) and algae red (auto-fluorescence of chlorophyll $a$ ). Scale bar refers to $250 \mu \mathrm{m}$.

bedforms inducing gradients of flow velocity and turbulence (Supplementary Figure 1). Though we did not explicitly study the temporal development of streamers, we sampled biofilms repeatedly depending on streamer development, which differed in both experimental setups (days 50, 62 and 83 of biofilm growth in the laboratory flumes; days 17 and 61 in the streamside flumes; see Supplementary information for details). Macroscopic streamers (minimum a few mm long; Figure 1a) were carefully separated from the biofilm base in the laboratory using sterile (ethanol-flamed) tweezers and dissection microscopy. In total, this resulted in 45 paired base and streamer samples from five growth stages and eight different hydrodynamic conditions (Supplementary Table 1). Denaturing gradient gel electrophoresis (DGGE) was carried out on all biofilm samples. In all, 54 clearly visible DGGE-bands were excised, the DNA fragment was reamplified and sequenced (see Supplementary information and Supplementary Figure 2). Sequences were analyzed using the software of the Ribosomal Database Project (Wang et al., 2007; Cole et al., 2009).

The community 'fingerprints' (from DGGE) were transferred into a band presence-absence matrix. DGGE-bands appearing at the same position on a gel were regarded as the same operational taxonomic unit (OTU). The similarity between the base and streamer of a given biofilm was calculated as the Sørensen's Index, $S I=2 S /\left(A_{1}+A_{2}\right)$, where $S$ is the number of shared OTUs, and $\mathrm{A}_{1}$ and $\mathrm{A}_{2}$ are the total numbers of OTUs in the respective samples. We carried out a fourth-corner analysis to test for differences in the distribution of phylogenetic groups between the biofilm base and streamers (Supplementary information). This analysis relates the biological attributes (in our case the phylogenetic affiliation) of organisms to the environmental conditions of their habitats (Legendre et al., 1997). Several permutation models have been proposed to test the overall null hypothesis that the attributes of an organism are unrelated to the environmental conditions. Permutation model 1 tests the hypothesis that species are found in locations where they encounter optimal living conditions versus the null hypothesis that all parts of the environment are equally suitable for all species (environmental control model). The number of locations occupied by a given species remains fixed and is considered to reflect characteristics of the species, such as abundance, intraspecific competition and ecological plasticity. Permutation model 2 does the same at the level of species assemblages, assuming strong biotic ties among the members of the community. Permutation model 3 tests the hypothesis that species have a competitive advantage in the location where they are found versus the null hypothesis that the identity (species) of an individual settling is a chance event (lottery model). In spite of holding the number of occurrences of a given species constant, it assumes a fixed number of niches available in a given location. Permutation model 4 differs from model 3 in the way that it tests the relevance of the biological attributes for given preferences of organisms for environmental conditions (Legendre et al., 1997; Dray and Legendre, 2008). We chose model 1 and 3 because they test two contrasting hypotheses and are less restrictive than model 2 and 4, which take the link between species and their traits (model 2) or the species preferences for sites (model 4) for granted (Legendre et al., 1997; Dray and Legendre, 2008). It should be noticed, however, that the fourth-corner analysis does not reveal the nature of the competition (for example, for resources).

We generally observed streamer development starting from several single filaments that merged to a broad 'head' and successively elongated into a 'tail', as also described from monospecies biofilms (for example, Stoodley et al., 1999). In nascent streamers, bacterial cells were initially mixed with small diatoms (Figure 1c) and the inclusion of further algae allowed streamers to develop remarkable length (up to several centimetres in the streamside flumes; Figures 1a and b). It should be noted that Diatoma microcolonies, but also filamentous algae, can form networks that provide stability and putatively elasticity to streamers; they may also provide exudates that support microbial heterotrophs within these complex assemblages. 
Average $\alpha$-diversity (that is, richness of OTUs as derived from DGGE) was significantly higher in the biofilm base than in the streamers $(P<0.001)$ when all the dates from both setups were pooled. No significant trend emerged across biofilm age (Figure 2a) or hydrodynamic treatment (data not shown). $\gamma$-diversity (that is, the total number of OTUs in base or streamers at a given date) and the numbers of OTUs specific for either base or streamers were also higher in the base (Figures $2 \mathrm{~b}$ and c) at four of the five sampling occasions. Collectively, these patterns point to a community shift between architectural features, such as streamers and the base, and support recent findings from an acidophilic biofilm (Wilmes et al., 2009).

The Sørensen's Index indicates that the community structure of the biofilm base and the streamers was generally more similar in the laboratory than in the streamside flumes (Figure 2d), which we tentatively attribute to scaling effects. Biofilms in the streamside flumes had more physical space available to develop long streamers often well aloof from the base. They were continuously exposed to fresh inoculum also including various algae as potential building blocks. The Sørensen's Index increased significantly $(P<0.05$ for the laboratory flumes, $P<0.01$ for the streamside flumes) with biofilm development in both systems (Figure 2d), suggesting successive convergence of the base and the streamer communities. Biofilm maturation could induce structural homogeneity due to the increased presence of larger building blocks (for example, algae) that shape the overall architecture (Besemer et al., 2007), and repeatedly observed sloughing may induce a certain turnover and loss of stratification of the community. In addition, protozoan grazing is known to affect bacterial growth and survival in biofilms (Matz et al., 2005) and may differentially shape community structure in the base and streamer.

The 54 prominent DGGE-bands sequenced for phylogenetic analysis yielded sequences of 29 OTUs - some of them repeatedly detected in the various samples (Figure 3 and Table 1). Sequences

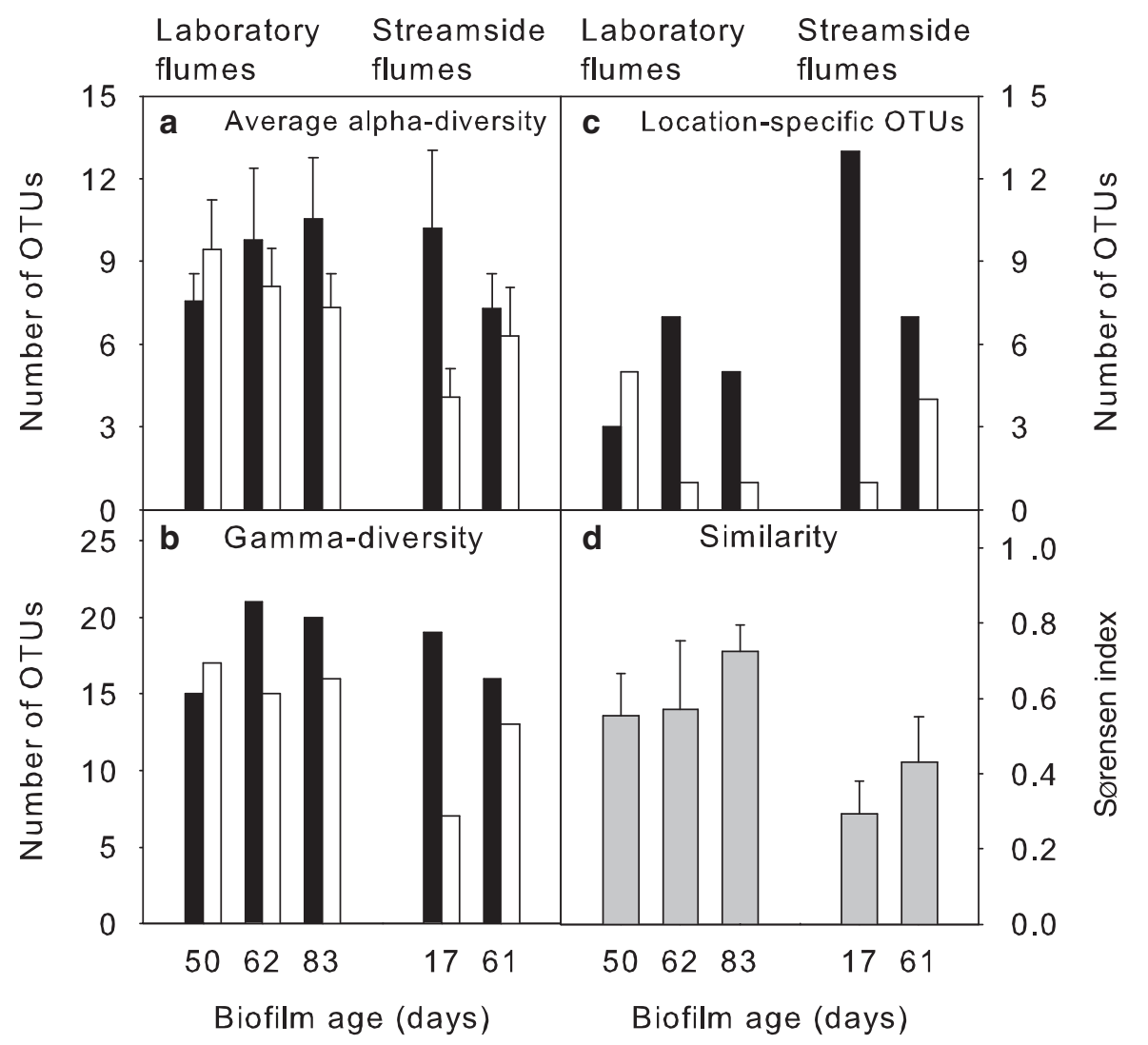

Figure 2 Numbers of operational taxonomic units (OTUs) in the biofilm base (black bars) and streamers (white bars) at different growth states. (a) Average $\alpha$-diversity (as richness). Error bars indicate the standard deviation ( $n=9$ for the laboratory flumes and $n=10$ for the streamside flumes experiment). (b) $\gamma$-diversity, as the total number of OTUs found in base (black bars) and streamers (white bars). (c) Number of OTUs specific for either the biofilm base (black bars) or streamers (white bars) for the respective sampling occasion. (d) Average similarity (as the Sørensen Index) between the biofilm base and the respective streamers of each sample. Error bars indicate the standard deviation ( $n=9$ for the laboratory flumes and $n=10$ for the streamside flumes experiment). The mean Sørensen Index was significantly higher at day 83 than at day 50 in the laboratory flumes (Kruskal-Wallis analysis of variance and Tamhane's test, $P<0.05$ ) and significantly higher at day 61 than at day 17 in the streamside flumes (Kruskal-Wallis analysis of variance $P<0.01$ ). 


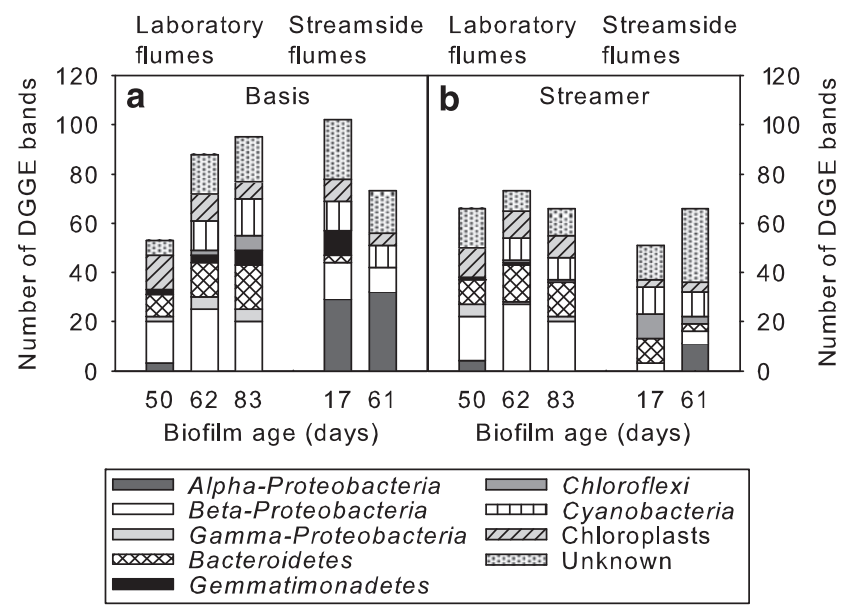

Figure 3 Frequency of operational taxonomic units related to phylogenetic groups in (a) the base and (b) the streamers of biofilms at different growth states.

were generally more closely related to published environmental sequences than to cultured bacteria. Most OTUs were classified as $\alpha$ - and $\beta$-Proteobacteria, members of the Bacteroidetes phylum, Cyanobacteria and algal chloroplasts. Several OTUs belonged to the $\gamma$-Proteobacteria and the Gemmatimonadetes group; one OTU was classified as a member of the Chloroflexi phylum, but was not closely related to any published sequence. The fourth-corner analysis on these phylogenetic groups showed significant differences in the distribution of phylogenetic groups between the biofilm base and the streamers (Table 2). The environmental control model (permutation model 1) showed that $\alpha$-Proteobacteria and Gemmatimonadetes members were preferentially found in the biofilm base compared with the streamers. The lottery model (permutation model 3) revealed $\alpha$-Proteobacteria and Gemmatimonadetes as comparatively weak competitors and $\beta$-Proteobacteria and Bacteroidetes as comparatively strong competitors in the streamers; the community structure in the biofilm base showed no significant deviation from randomness. Together with the lower richness observed in the streamers, these results might indicate that streamers constitute a more competitive biofilm zone than the biofilm base.

Similar to the fourth-corner analysis, OTU frequencies were related to both biofilm zones using G-statistics and permutations to acquire better resolution on the shifts in the community structure (Supplementary Table 2). More than 50\% of the identified OTUs deviated significantly from random distribution. Not unexpectedly, the behavior of OTUs differed remarkably within a given phylogenetic group. Only one $\alpha$-Proteobacterium (OTU 8 ), likely an endosymbiont of Acanthamoeba (Table 1), was under-represented in the biofilm. The other $\alpha$ Proteobacteria were affiliated to the Sphingomonadaceae family, members of which were reported to pioneer biofilm formation (for example, Pang and Liu, 2006; Zhang et al., 2006). Further, members of this group were shown to copiously produce exopolymers (Venugopalan et al., 2005) and to coaggregate with other biofilm members (Rickard et al., 2002), abilities that may be advantageous to colonization and early biofilm formation. We suggest that these OTUs were among the initial biofilm formers and that their populations persisted in the base, whereas stronger competitors built-up the biofilm canopy, including streamers.

Several OTUs affiliated to the $\beta$-Proteobacteria, Bacteroidetes and Cyanobacteria identified in this study are related to genera possessing filamentous morphology (for example, Lewinella, Haliscomenobacter and Tychonema bourellyi; Schauer and Hahn, 2005) or which form chains (for example, Arcicella; Manz et al., 1999; Nikitin et al., 2004). Though it is certainly difficult to draw conclusions about bacterial phenotypes from their phylogenetic affiliation, we hypothesize that filamentous or filamentforming cells may be advantageous for life in streamers. For instance, Kindaichi et al. (2004) predominantly observed filamentous Bacteroidetes in the canopy of autotrophic biofilms, whereas single Proteobacteria were present throughout the whole biofilm. Motility by gliding or flagella may also have a role for the successful colonization of streamers and contribute to the diversification of base and streamer communities. For instance, in Pseudomonas aeruginosa biofilms, migrating cells climb the stalks and form the mushroom caps-a process driven by type-IV pili and putatively induced by the search for nutrients (Klausen et al., 2003).

We do recognize the potential limitations of DGGE and sequencing. For instance, it does not show the exact spatial organization of the various bacterial species as would have been shown by other techniques (for example, Wilmes et al., 2009). However, largely used in ecological studies on community structure (for example, Jackson et al., 2001), DGGE enables the throughput and data acquisition required by fourth-corner analysis, for instance, to address ecological questions.

In summary, our results indicate pattern congruency between architectural differentiation and community structure in stream biofilms. We suggest this micro-scale differentiation as a potentially important adaptation to the dynamics (for example, flow, resource availability) of natural ecosystems-comparable to the phenotypic diversification in bacterial biofilms as a survival strategy under adverse conditions (Koh et al., 2007). Flow and resources are highly heterogeneous in sedimentary ecosystems, thereby creating divers microhabitats with ample opportunities for biofilms to differentiate into complex architecture and accompanying community structures. Eventually, this may contribute to the high prokaryotic biodiversity in sedimentary ecosystems. 
Table 1 Phylogenetic affiliation of sequences obtained for dominant DGGE-bands

\begin{tabular}{|c|c|c|c|c|c|}
\hline OTU no. ${ }^{\mathrm{a}}$ & $\begin{array}{l}\text { Phylogenetic } \\
\text { group }\end{array}$ & $\begin{array}{l}\text { Closest relative } \\
\text { (accession number) }^{\mathrm{c}}\end{array}$ & $\begin{array}{l}\text { Similarity } \\
(\%)\end{array}$ & $\begin{array}{l}\text { Closest cultured relative } \\
\text { (accession number) }^{\mathrm{c}, \mathrm{d}}\end{array}$ & $\underset{(\%)}{\text { Similarity }}$ \\
\hline $\begin{array}{l}\text { OTU } 8 \\
\text { (EF188846) }\end{array}$ & $\alpha$-Proteobacteria & Uncultured bacterium (AJ965830) & 0.943 & $\begin{array}{l}\text { Candidatus Odyssella thessalonicensis } \\
\text { (AF069496) }\end{array}$ & 0.694 \\
\hline $\begin{array}{l}\text { OTU } 9 \\
\text { (FJ796385) }\end{array}$ & $\alpha$-Proteobacteria & Sphingomonas sp. (AY584572) & 1.000 & Novosphingobium hassiacum (AJ416411) & 0.805 \\
\hline $\begin{array}{l}\text { OTU } 10 \\
\text { (FJ796386) }\end{array}$ & $\alpha$-Proteobacteria & Uncultured bacterium (FM872965) & 0.981 & Novosphingobium lentum (AJ303009) & 0.826 \\
\hline $\begin{array}{l}\text { OTU } 11 \\
\text { (FJ796387) }\end{array}$ & $\alpha$-Proteobacteria & Alpha proteobacterium (AF235997) & 1.000 & Novosphingobium lentum (AJ303009) & 0.847 \\
\hline $\begin{array}{l}\text { OTU } 12 \\
\text { (FJ796395) }\end{array}$ & $\alpha$-Proteobacteria & $\begin{array}{l}\text { Uncultured alpha proteobacterium } \\
\text { (AJ867917) }\end{array}$ & 1.000 & Sphingomonas yabuuchiae (AB071955) & 0.784 \\
\hline $\begin{array}{l}\text { OTU } 1 \\
\text { (EF396239) }\end{array}$ & $\beta$-Proteobacteria & $\begin{array}{l}\text { Hydrogenophaga atypical } \\
\text { (AJ585992) }\end{array}$ & 0.963 & Hydrogenophaga atypical (AJ585992) & 0.963 \\
\hline $\begin{array}{l}\text { OTU } 2 \\
\text { (EF396241) }\end{array}$ & $\beta$-Proteobacteria & Uncultured bacterium (EU491796) & 0.986 & Herbaspirillum seropedicae (Y10146) & 0.766 \\
\hline $\begin{array}{l}\text { OTU } 4 \\
\text { (EF396242) }\end{array}$ & $\beta$-Proteobacteria & Uncultured bacterium (DQ337076) & 0.990 & Azoarcus evansii (X77679) & 0.790 \\
\hline $\begin{array}{l}\text { OTU } 13 \\
\text { (FJ796388) }\end{array}$ & $\beta$-Proteobacteria & Uncultured bacterium (EU443091) & 0.986 & Mitsuaria chitosanitabida (АВ006851) & 0.901 \\
\hline $\begin{array}{l}\text { OTU } 14 \\
\text { (FJ796389) }\end{array}$ & $\beta$-Proteobacteria & $\begin{array}{l}\text { Uncultured hydrogenophaga sp. } \\
\text { (AF523009) }\end{array}$ & 0.986 & Hydrogenophaga atypical (AJ585992) & 0.942 \\
\hline $\begin{array}{l}\text { OTU } 15 \\
\text { (FJ796392) }\end{array}$ & $\beta$-Proteobacteria & Uncultured organism (AY707574) & 1.000 & Leptothrix mobilis (X97071) & 0.907 \\
\hline $\begin{array}{l}\text { OTU } 16 \\
\text { (FJ796403) }\end{array}$ & $\beta$-Proteobacteria & $\begin{array}{l}\text { Commamonadaceae bacterium } \\
\text { (AJ556799) }\end{array}$ & 0.990 & Aquabacterium parvum (AF035052) & 0.875 \\
\hline $\begin{array}{l}\text { OTU } 7 \\
\text { (EF451827) }\end{array}$ & $\gamma$-Proteobacteria & Uncultured bacterium (AM158337) & 0.992 & Lysobacter koreensis (AB166878) & 0.857 \\
\hline $\begin{array}{l}\text { OTU } 6 \\
\text { (EF451826) }\end{array}$ & Bacteroidetes & Uncultured bacterium (AY863079) & 0.644 & Lewinella cohaerens (AF039292) & 0.537 \\
\hline $\begin{array}{l}\text { OTU } 17 \\
\text { (FJ796383) }\end{array}$ & Bacteroidetes & Flectobacillus sp. (AY584583) & 0.971 & Arcicella aquatica (AJ535729) & 0.883 \\
\hline $\begin{array}{l}\text { OTU } 18 \\
\text { (FJ796394) }\end{array}$ & Bacteroidetes & Uncultured bacterium (EU104120) & 0.985 & Haliscomenobacter hydrossis (M58790) & 0.836 \\
\hline $\begin{array}{l}\text { OTU } 19 \\
\text { (FJ796398) }\end{array}$ & Bacteroidetes & Uncultured bacterium (EU101256) & 0.772 & Lewinella persicus (AF039295) & 0.475 \\
\hline $\begin{array}{l}\text { OTU } 20 \\
\text { (FJ796400) }\end{array}$ & Chloroflexi & Uncultured bacterium (EF208597) & 0.771 & $\begin{array}{l}\text { Thermoanaerobacter } \\
\text { thermohydrosulfuricus (L09161) }\end{array}$ & 0.385 \\
\hline $\begin{array}{l}\text { OTU } 21 \\
\text { (FJ796390) }\end{array}$ & Gemmatimonadetes & Uncultured bacterium (DQ521491) & 0.951 & Gemmatimonas aurantiaca (AB072735) & 0.699 \\
\hline $\begin{array}{l}\text { OTU } 22 \\
\text { (FJ796401) }\end{array}$ & Gemmatimonadetes & Uncultured bacterium (FJ392347) & 0.970 & Gemmatimonas aurantiaca (AB072735) & 0.711 \\
\hline $\begin{array}{l}\text { OTU } 23 \\
\text { (FJ796382) }\end{array}$ & Cyanobacteria & Tychonema bourrellyi (AB045897) & 0.988 & Nostoc punctiforme (AF027655) & 0.634 \\
\hline $\begin{array}{l}\text { OTU } 24 \\
\text { (FJ796396) }\end{array}$ & Cyanobacteria & Uncultured bacterium (EF451617) & 0.899 & Oscillatoria acuminata (AB039014) & 0.564 \\
\hline $\begin{array}{l}\text { OTU } 25 \\
\text { (FJ796397) }\end{array}$ & Cyanobacteria & $\begin{array}{l}\text { Uncultured cyanobacterium } \\
\text { (DQ181677) }\end{array}$ & 0.870 & Chroococcidiopsis thermalis (АВ039005) & 0.598 \\
\hline $\begin{array}{l}\text { OTU } 26 \\
\text { (FJ796399) }\end{array}$ & Cyanobacteria & $\begin{array}{l}\text { Uncultured cyanobacterium } \\
\text { (DQ531865) }\end{array}$ & 0.991 & Chroococcidiopsis thermalis (AB039005) & 0.549 \\
\hline $\begin{array}{l}\text { OTU } 5 \\
\text { (EF396243) }\end{array}$ & $\begin{array}{l}\text { Streptophyta } \\
\text { chloroplast }\end{array}$ & $\begin{array}{l}\text { Zygnema circum-carinatum } \\
\text { (AY958086) }\end{array}$ & 0.573 & Nodularia spumigena (AB039002) & 0.449 \\
\hline $\begin{array}{l}\text { OTU } 27 \\
\text { (FJ796384) }\end{array}$ & $\begin{array}{l}\text { Bacillariophyta } \\
\text { chloroplast }\end{array}$ & $\begin{array}{l}\text { Uncultured cyanobacterium } \\
\text { (DQ130046) }\end{array}$ & 1.000 & Nodularia spumigena (АВ039002) & 0.477 \\
\hline $\begin{array}{l}\text { OTU } 28 \\
\text { (FJ796391) }\end{array}$ & $\begin{array}{l}\text { Bacillariophyta } \\
\text { chloroplast }\end{array}$ & Uncultured bacterium (EU376191) & 0.881 & Chroococcidiopsis thermalis (AB039005) & 0.484 \\
\hline $\begin{array}{l}\text { OTU } 29 \\
\text { (FJ796393) }\end{array}$ & $\begin{array}{l}\text { Chlorophyta } \\
\text { chloroplast }\end{array}$ & $\begin{array}{l}\text { Uncultured cyanobacterium } \\
\text { (DQ366074) }\end{array}$ & 0.956 & Nodularia spumigena (AB039002) & 0.423 \\
\hline $\begin{array}{l}\text { OTU } 30 \\
\text { (FJ796402) }\end{array}$ & $\begin{array}{l}\text { Chlorophyta } \\
\text { chloroplast }\end{array}$ & Scenedesmus obliquus (DQ396875) & 0.945 & Nodularia spumigena (АВ039002) & 0.374 \\
\hline
\end{tabular}

Abbreviation: DGGE, denaturing gradient gel electrophoresis and OTU, operational taxonomic unit.

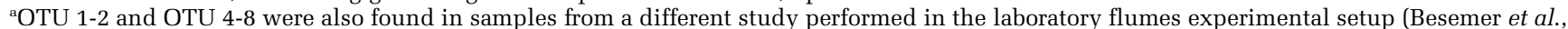
2007). To avoid ambiguities, the numbers of these OTUs were retained and the novel OTUs were numbered continuously OTU 9 to OTU 30.

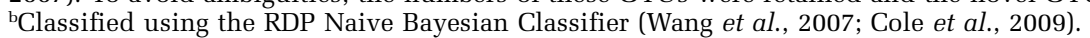

'Estimated by comparison to the Ribosomal Database Project II database (February 2009).

dSpecies type strains. 
Table 2 Frequency of occurrences and results of the fourth-corner analysis of the distribution of phylogenetic groups classified by the Naïve Bayesian rRNA Classifier Version 2.0 provided by the Ribosomal Database Project (Wang et al., 2007) in biofilm basis and streamer

\begin{tabular}{|c|c|c|c|c|c|}
\hline & \multirow[t]{2}{*}{ Occurrence basis/canopy } & \multicolumn{2}{|c|}{ Env. control model } & \multicolumn{2}{|c|}{ Lottery model } \\
\hline & & Basis & Canopy & Basis & Canopy \\
\hline Global test (G-statistics) & & \multicolumn{2}{|c|}{$P<0.001$} & \multicolumn{2}{|c|}{$P<0.001$} \\
\hline$\alpha$-Proteobacteria & $64 / 15$ & $\begin{array}{c}\text { overrep. } \\
P<0.01\end{array}$ & $\begin{array}{c}\text { underrep. } \\
P<0.01\end{array}$ & - & $\begin{array}{c}\text { underrep. } \\
P<0.01\end{array}$ \\
\hline$\beta$-Proteobacteria & $87 / 73$ & - & - & - & $\begin{array}{l}\text { overrep. } \\
P<0.01\end{array}$ \\
\hline$\gamma$-Proteobacteria & $12 / 8$ & - & - & - & - \\
\hline Bacteroidetes & $44 / 52$ & - & - & - & $\begin{array}{l}\text { overrep. } \\
P<0.01\end{array}$ \\
\hline Cloroflexi & $8 / 2$ & - & - & - & - \\
\hline Gemmatimonadetes & $21 / 2$ & $\begin{array}{c}\text { overrep. } \\
P<0.01\end{array}$ & $\begin{array}{c}\text { underrep. } \\
P<0.01\end{array}$ & - & $\begin{array}{c}\text { underrep. } \\
P<0.01\end{array}$ \\
\hline Cyanobacteria & $48 / 39$ & - & - & - & - \\
\hline Chloroplasts & $46 / 39$ & - & - & - & - \\
\hline
\end{tabular}

Abbreviations: env., environmental; overrep., overrepresented; underrep., underrepresented.

$P$-values were estimated using G-statistics.

\section{Acknowledgements}

We thank G Hochedlinger, A-K Chlup, G Steniczka, C Preiler, C Baranyi, M Roura-Carol, E Sollböck and $\mathrm{H}$ Hofreiter for their help in the laboratory and in the field. This research was supported by grants of the Austrian Science Fund (P16935-B03) and the European Science Foundation (COMIX, AI0004321) to TJB.

\section{References}

Besemer K, Singer G, Limberger R, Chlup AK, Hochedlinger G, Hödl I et al. (2007). Biophysical controls on community succession in stream biofilms. Appl Environ Microbiol 73: 4966-4974.

Cole JR, Wang Q, Cardenas E, Fish J, Chai B, Farris RJ et al. (2009). The Ribosomal Database Project: improved alignments and new tools for rRNA analysis. Nucleic Acids Res 37: D141-D145.

Costerton JW, Lewandowski Z, Caldwell DE, Korber DR, Lappin-Scott HM. (1995). Microbial biofilms. Annu Rev Microbiol 49: 711-745.

Dray S, Legendre P. (2008). Testing the species traitsenvironment relationships: the fourth-corner problem revisited. Ecology 89: 3400-3412.

Hall-Stoodley L, Costerton JW, Stoodley P. (2004). Bacterial biofilms: From the natural environment to infectious diseases. Nat Rev Microbiol 2: 95-108.

Hallberg KB, Coupland K, Kimura S, Johnson DB. (2006). Macroscopic streamer growths in acidic, metal-rich mine waters in North Wales consist of novel and remarkably simple bacterial communities. Appl Environ Microbiol 72: 2022-2030.

Jackson CR, Churchill PF, Roden EE. (2001). Successional changes in bacterial assemblage structure during epilithic biofilm development. Ecology 82: 555-566.

Kindaichi T, Ito T, Okabe S. (2004). Ecophysiological interaction between nitrifying bacteria and heterotrophic bacteria in autotrophic nitrifying biofilms as determined by microautoradiography-fluorescence in situ hybridization. Appl Environ Microbiol 70: 1641-1650.
Klausen M, Aaes-Jørgensen A, Molin S, Tolker-Nielsen T. (2003). Involvement of bacterial migration in the development of complex multicellular structures in Pseudomonas aeruginosa biofilms. Mol Microbiol 50: 61-68.

Koh KS, Lam KW, Alhede M, Queck SY, Labbate M, Kjelleberg S et al. (2007). Phenotypic diversification and adaptation of Serratia marcescens MG1 biofilmderived morphotypes. J Bacteriol 189: 119-130.

Legendre P, Galzin R, Harmelin-Vivien ML. (1997). Relating behavior to habitat: solutions to the fourthcorner problem. Ecology 78: 547-562.

Manz W, Wendt-Potthoff K, Neu TR, Szewzyk U, Lawrence JR. (1999). Phylogenetic composition, spatial structure, and dynamics of lotic bacterial biofilms investigated by fluorescent in situ hybridization and confocal laser scanning microscopy. Microb Ecol 37: 225-237.

Matz C, McDougald D, Moreno AM, Yung PY, Yildiz FH, Kjelleberg S. (2005). Biofilm formation and phenotypic variation enhance predation-driven persistence of Vibrio cholerae. Proc Natl Acad Sci USA 102: 16819-16824.

Nikitin DI, Strömpl C, Oranskaya MS, Abraham W-R. (2004). Phylogeny of the ring-forming bacterium Arcicella aquatica gen. nov., sp. nov. (ex Nikitin et al. 1994), from a freshwater neuston biofilm. Int $J$ Syst Evol Microbiol 54: 681-684.

Pang CM, Liu W-T. (2006). Biological filtration limits carbon availability and affects downstream biofilm formation and community structure. Appl Environ Microbiol 72: 5702-5712.

Rickard AH, Leach SA, Hall LS, Buswell CM, High NJ, Handley PS. (2002). Phylogenetic relationships and coaggregation ability of freshwater biofilm bacteria. Appl Environ Microbiol 68: 3644-3650.

Schauer M, Hahn MW. (2005). Diversity and phylogenetic affiliations of morphologically conspicuous large filamentous bacteria occurring in the pelagic zones of a broad spectrum of freshwater habitats. Appl Environ Microbiol 71: 1931-1940.

Singer G, Besemer K, Hödl I, Chlup AK, Hochedlinger G, Stadler $\mathrm{P}$ et al. (2006). Microcosm design and evaluation 
to study stream microbial biofilms. Limnol Oceanogr Meth 4: 436-447.

Stoodley P, Lewandowski Z, Boyle JD, Lappin-Scott HM. (1999). Structural deformation of bacterial biofilms caused by short-term fluctuations in fluid shear: An in situ investigation of biofilm rheology. Biotechnol Bioeng 65: 83-92.

Venugopalan VP, Kuehn M, Hausner M, Springael D, Wilderer PA, Wuertz S. (2005). Architecture of a nascent Sphingomonas sp. biofilm under varied hydrodynamic conditions. Appl Environ Microbiol 71: 2677-2686.

Wang Q, Garrity GM, Tiedje JM, Cole JR. (2007). Naïve Bayesian Classifier for Rapid Assignment of rRNA
Sequences into the New Bacterial Taxonomy. Appl Environ Microbiol 73: 5261-5267.

Whitman WB, Coleman DC, Wiebe WJ. (1998). Prokaryotes: The unseen majority. Proc Natl Acad Sci USA 95: 6578-6583.

Wilmes P, Remis JP, Hwang M, Auer M, Thelen MP, Banfield JF. (2009). Natural acidophilic biofilm communities reflect distinct organismal and functional organization. ISME J 3: 266-270.

Zhang K, Choi H, Dionysiou DD, Sorial GA, Oerther DB. (2006). Identifying pioneer bacterial species responsible for biofouling membrane bioreactors. Environ Microbiol 8: 433-440.

Supplementary Information accompanies the paper on The ISME Journal website (http://www.nature.com/ismej) 